\title{
Formy wspierania klastrów w ramach funduszy strukturalnych Unili Europejskiej
}

\author{
Małgorzata Baran
}

\section{Wprowadzenie}

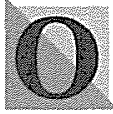

bserwacje zjawisk zachodzących w gospodarkach, zwłaszcza krajów rozwiniętych, pokazują, że klastry (clusters) mają wpływ na innowacyjność i konkurencyjność zarówno przedsiębiorstw je tworzących, jak i gospodarek lokalnych i regionalnych. Koncepcja tworzenia klastrów zakłada, że gospodarka to nie tylko tworzące ją podmioty $\mathrm{i}$ instytucje, ale też efekty synergii, jakie powstają w wyniku ich wzajemnej współpracy. Zgodnie z definicją prekursora teorii klastrów, M.E. Portera, klaster to "geograficzne skupisko wzajemnie powiąanych firm, wyspecjalizowanych dostawców, jednostek świadczących usługi, firm działających w pokrewnych sektorach i związanych z nimi instytucji (na przykład uniwersytetów, jednostek normalizacyjnych i stowarzyszeń branżowych) w poszczególnych dziedzinach konkurujących między sobą, ale również współpracujących. Klastry osiągające masę krytyczną (niezbędna liczba firm i innych instytucji tworzaca efekt aglomeracji) i odnoszące niezwykłe sukcesy konkurencyjne w określonych dziedzinach działalności są cechą charakterystyczną niemal każdej gospodarki narodowej, regionalnej, stanowej, a nawet wielkomiejskiej, głównie w krajach rozwiniętych" [5, s. 248]. M.E. Porter wskazuje, że klastry są zdeterminowane takimi elementami, jak: geograficzne skupienie, specjalizacja, obecność firm wraz z innymi instytucjami oraz współzależność (współpraca). Przedsiębiorstwa klastra połączone są z otoczeniem bliższym i dalszym powiązaniami o charakterze pionowym (dostawcy i odbiorcy współpracujący w łańcuchu wartości) i poziomym (wspólni klienci, technologie, kanały dystrybucji). Te pierwsze dotycza zjawiska kooperacji, natomiast drugi typ powiązań jest typowy dla zjawiska konkurencji [5, s. 246-249].

Wspieranie rozwoju gospodarczego regionów oparte na klastrach jest nowym narzędziem prowadzenia polityki regionalnej w Polsce. Rozwijające się klastry charakteryzują się dynamicznym wzrostem liczby narodzin nowych przedsiębiorstw (nowe miejsca pracy), co wpływa na rozwój regionu. Jednocześnie wzmacniane są struktury wiążące przedsiębiorstwa $\mathrm{z}$ ich lokalnym otoczeniem, co wplywa na podnoszenie poziomu konkurencyjności gospodarki lokalnej, regionalnej, a nawet narodowej.

\section{Klastry w polityce Unii Europejskiej}

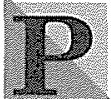

ostrzeganie gospodarki przez pryzmat koncepcji klastrów daje nowe spojrzenie na charakter polityki publicznej i sposób wspierania przedsiębiorstw w klastrach. Dużą aktywność w propagowaniu koncepcji klastrów przejawia Organizacja Współpracy i Rozwoju Gospodarczego oraz Komisja Europejska. Klastry jako instrument tworzenia innowacji w gospodarce globalnej zyskały zainteresowanie badaczy OECD i znalazły odzwierciedlenie w prowadzonych analizach $\mathrm{i}$ badaniach. Wspieranie funkcjonowania i rozwoju klastrów znajduje również zastosowanie $\mathrm{w}$ instrumentarium polityki rozwoju regionalnego oraz innowacji i badań w ramach inicjatyw Komisji Europejskiej [8, s. 6-8].

Komisja Europejska w wielu dokumentach odnosi się do fenomenu klastrów jako jednej z kluczowych determinant potencjału gospodarczego we współczesnej gospodarce. Tworzenie klastrów oraz wspieranie ich rozwoju Komisja Europejska uznaje za istotny priorytet nowej polityki przemysłowej. Według Komisji Europejskiej państwa członkowskie oraz władze lokalne powinny aktywnie włączyć się w stymulowanie efektywnego rozpowszechniania wiedzy i technologii pomiędzy przedsiębiorstwami m.in. poprzez pobudzanie inicjatyw opartych na klastrach w celu skutecznego podnoszenia poziomu konkurencyjności gospodarek poszczególnych regionów Unii Europejskiej. $\mathrm{Z}$ tego też względu w ramach wspólnotowej polityki strukturalnej (w ramach perspektywy finansowej 2007-2013) przewiduje się wsparcie działan typowych dla polityki rozwoju opartej na klastrach [1, s. 11-13].

\section{Wsparcie klastrów w Programach Operacyjnych 2007-2013}

\section{Program Operacyjny „Innowacyjna Gospodarka”}

Klastry jako forma współpracy prowadząca do wzrostu innowacyjności, efektywności i konkurencyjności przedsiębiorstw będa rozwijane i wspierane w Polsce w nowym okresie programowania w latach 2007-2013 zgodnie z zapisami Programu Operacyjnego „Innowacyjna Gospodarka” [6, s. 80-83]. Główny cel tego programu zakłada rozwój polskiej gospodarki oparty na innowacyjności przedsiębiorstw. Złożony jest z następujących celów szczegółowych: 
- zwiększenie innowacyjności przedsiębiorstw,

- wzrost konkurencyjności polskiej nauki,

- zwiększenie roli nauki w rozwoju gospodarczym,

- zwiększenie udziału innowacyjnych produktów polskiej gospodarki w rynku międzynarodowym,

- tworzenie trwałych i lepszych miejsc pracy.

Cele te będą osiągnięte poprzez realizację następujących działań:

- wspieranie badań i rozwoju technologicznego, innowacyjności i przedsiębiorczości, w tym wzmocnienie zdolności w zakresie badań i rozwoju technologicznego na szczeblu regionalnym,

- wspieranie badań i rozwoju technologicznego w MSP,

- transfer technologii,

- wzmocnienie kontaktów pomiędzy MŚP a ośrodkami akademickimi i centrami badawczymi,

- rozwój instytucji otoczenia biznesu oraz klastrów,

- wspieranie dostępności usług biznesowych i technologicznych dla grup MŚP, promowanie finansowania przedsiębiorczości i innowacji w MŚP poprzez nowe instrumenty finansowe.

W ramach Programu Operacyjnego „Innowacyjna Gospodarka" wyróżniono osiem priorytetów, jako kluczowe kierunki działań zaplanowane do realizacji w nowym okresie programowania:

- badania i rozwój nowoczesnych technologii,

- infrastruktura B+R,

- kapitał dla innowacji,

- inwestycje w innowacyjne przedsięwzięcia,

- dyfuzja innowacji,

- polska gospodarka na rynku międzynarodowym,

- informatyzacja administracji na rzecz przedsiębiorstw,

- pomoc techniczna.

Wśród wielu wymienionych priorytetów, dyfuzja innowacji dotyczy wspierania klastrów oraz rozwoju sieci wspólpracy pomiędzy przedsiębiorstwami. Wskazuje się $\mathrm{w}$ dokumencie, ze wspomaganie tworzenia klastrów jest jednym $\mathrm{z}$ głównych zadań instytucji otoczenia biznesu. Podkreśla się również zalety aktywnego uczestnictwa firm w rozwiniętym, dojrzałym klastrze. Dzięki współtworzeniu klastra przedsiębiorstwa mogą realizować wspólnie konkretne przedsięwzięcia, podejmować wspólne działania (zlecanie badań, wspólne inwestycje, poszukiwanie poddostawców), które w perspektywie długookresowej mogą doprowadzić do wzrostu potencjału i efektywności przedsiębiorstw. Dlatego ważne dla wzrostu innowacyjności gospodarki jest, aby nowe rozwiązania kreowane i stosowane przez podmioty gospodarcze, jednostki naukowe $\mathrm{i}$ inne instytucje otoczenia biznesu były rozpowszechniane i udostępniane, a w konsekwencji wykorzystywane w jak najszerszym zakresie. Dzięki dyfuzji innowacji możliwe jest tworzenie nowych rozwiązan w przedsiębiorstwie i polepszenie jego pozycji konkurencyjnej. Dyfuzję umożliwia stała współpraca pomiędzy użytkownikami nowych rozwiązań.

Jak wskazują przykłady krajów rozwiniętych, kooperacja przedsiębiorstw w ramach klastrów niesie określone korzyści zarówno dla przedsiębiorstw je tworzących, jak również dla regionu, w którym występują. Można wymienić następujące rodzaje korzyści uzyskiwanych przez podmioty klastra $[2$, s. $8-9 ; 3$, s. 14-19]:
- zwiększona produktywność poprzez korzyści skali, umożliwiona dzięki specjalizacji czynników, takich jak siła robocza, źródła $B+R$ i technologie, mechanizmy venture capital itp.,

- oszczędność kosztów dzięki niższym kosztom transakcyjnym, oferowanym przez bliskość geograficzną,

- łatwiejszy i pełniejszy dostęp do informacji na temat zmian rynku, nowych technologii,

- poprawiony wizerunek i atrakcyjność obszaru, co prowadzi do większych możliwości przyciągnięcia firm zewnętrznych oraz kreowania nowych przedsiębiorstw, - możliwości szybszej reakcji na zmiany w otoczeniu (wiedzę technologiczną, praktykę zarządzania, możliwości marketingowe),

- możliwości wspólnego uczenia się poprzez wspólne poszukiwanie działań innowacyjnych, wykorzystanie efektu synergii pomiędzy firmami.

Z punktu widzenia całej gospodarki współdziałanie przedsiębiorstw w klastrze przynosi znaczącą wartość dodaną w porównaniu do działań podejmowanych przez pojedyncze podmioty. Współpraca pomiędzy firmami, instytucjami otoczenia biznesu a jednostkami naukowymi stwarza dogodne warunki do wypracowania i upowszechniania nowych rozwiązań technologicznych czy produktowych, a także wymiany doświadczeń, lepszego wykorzystania zasobów posiadanych przez uczestników klastra.

Celem priorytetu (dyfuzja innowacji) jest zapewnienie przedsiębiorcom wysokiej jakości usług służących wzmocnieniu oraz wykorzystaniu ich potencjału innowacyjnego oraz tworzenie korzystnych warunków współpracy przyczyniających się do wzmocnienia pozycji konkurencyjnej przedsiębiorstw. Wsparcie w ramach priorytetu przeznaczone będzie na projekty i przedsięwzięcia majace na celu budowę i rozwój powiązań kooperacyjnych przedsiębiorców o charakterze ponadregionalnym. Działania promocyjne pozwolą na zwiększenie świadomości z korzyści wynikających z kooperacji i podejmowania współpracy z jednostkami naukowymi. Ponadto $w$ priorytecie przewidziane jest wsparcie wzrostu innowacyjności przedsiębiorstw za pośrednictwem instytucji otoczenia biznesu - zarówno działających w sieciach o zasięgu krajowym, jak i pojedynczych wysoko wyspecjalizowanych ośrodków wspierania innowacyjności o istotnym znaczeniu w skali całej gospodarki kraju. Instytucje te przyczyniają się do wzmocnienia powiązań przedsiębiorców $\mathrm{z}$ jednostkami naukowymi poprzez udostępnianie odpowiedniej infrastruktury i wiedzy niezbędnej do prowadzenia działalności gospodarczej z wykorzystaniem nowych rozwiązań.

W ramach priorytetu wspierane będą m.in. następujące działania:

- inwestycje związane z pokryciem kosztów zainicjowania lub prowadzenia działalności kooperacyjnej,

- projekty inwestycyjne realizowane przez innowacyjne sieci otoczenia biznesu,

- projekty inwestycyjne realizowane przez proinnowacyjne instytucje otoczenia biznesu (m.in. parki naukowo-technologiczne, inkubatory technologii, centra transferu technologii),

- projekty doradcze, szkoleniowe i promocyjne wynikające ze strategii realizowanej przez innowacyjne sieci otoczenia biznesu, 
- projekty doradcze, szkoleniowe i promocyjne wynikające ze strategii realizowanej przez proinnowacyjne instytucje otoczenia biznesu,

- projekty doradcze, szkoleniowe, promocyjne oraz inwestycyjne związane ze wsparciem wykorzystania praw własności przemysłowej oraz praw autorskich i pokrewnych.

Budżet priorytetu na lata 2007-2013

\begin{tabular}{|l|c|c|c|}
\hline Priorytet V & Lącznie & EFRR & $\begin{array}{c}\text { Środki } \\
\text { krajowe }\end{array}$ \\
\hline $\begin{array}{l}\text { Dyfuzja } \\
\text { innowacji }\end{array}$ & $\begin{array}{c}894 \mathrm{mln} \\
\text { EUR }\end{array}$ & $\begin{array}{c}759,90 \mathrm{mln} \\
\text { EUR }\end{array}$ & $\begin{array}{c}131,1 \mathrm{mln} \\
\text { EUR }\end{array}$ \\
\hline
\end{tabular}

\section{Program Operacyjny „Kapital Ludzki”}

Kolejnym sposobem wspierania klastrów są działania promocyjne, szkoleniowo-doradcze oraz informacyjne planowane do realizacji w ramach Programu Operacyjnego „Kapitał Ludzki” [7, s. 90-92]. Głównym celem programu jest wzrost poziomu zatrudnienia i spójności społecznej, a idea funkcjonowania klastrów postrzegana jest jako jeden ze środków do jego realizacji. Klastrom poświęcony jest w szczególności priorytet drugi (rozwój zasobów ludzkich i potencjału adaptacyjnego przedsiębiorstw), który ukierunkowany jest na podniesienie konkurencyjności przedsiębiorstw przez zwiększenie inwestowania w kapitał ludzki przedsiębiorstw, poprawę jakości i dostępności usług szkoleniowo-doradczych wspierających rozwój przedsiębiorczości. Priorytet ten będzie realizowany poprzez cele szczegółowe (wytyczające kierunki działań):

- rozwój kadr nowoczesnej gospodarki,

- wykorzystanie e-learningu na rzecz podnoszenia kwalifikacji kadr przedsiębiorstw oraz rozwoju przedsiębiorczości,

- wsparcie systemu adaptacyjności kadr,

- projekty innowacyjne i współpraca ponadnarodowa.

W ramach rozwoju kadr nowoczesnej gospodarki będą podejmowane inicjatywy na rzecz klastrów, tj. popularyzowanie powiązań kooperacyjnych wśród przedsiębiorstw celem transferu wiedzy, wsparcie instytucji otoczenia biznesu w zakresie promowania działalności kooperacyjnej (np. mapowanie klastrów, popularyzacja i wymiana najlepszych praktyk), wspieranie współpracy przedsiębiorstw w zakresie tworzenia i zarządzania strukturą organizacyjną powiązania kooperacyjnego.

$\mathrm{Z}$ kolei w ramach wsparcia systemu adaptacyjności kadr będą wspierane projekty mające na celu tworzenie i rozwój istniejących instytucji świadczących usługi na rzecz rozwoju przedsiębiorczości oraz ich sieci, wsparcie kompleksowych usług dla przedsiębiorców oraz osób pragnących rozpocząć działalność gospodarcza, tworzenie i utrzymanie sieci regionalnych centrów wiedzy oraz jednostki nadzorującej centra na poziomie krajowym.

Oba wymienione Programy Operacyjne są komplementarne $\mathrm{z}$ działaniami planowanymi do realizacji w latach 2007-2013 w ramach Regionalnych Programów Operacyjnych, również w zakresie wsparcia klastrów o zasięgu regionalnym.

Planowane w Programach Operacyjnych działania mogą odegrać ważną rolę w inicjowaniu i stymulowa-
Budżet priorytetu na lata 2007-2013

\begin{tabular}{|c|c|c|c|}
\hline \multicolumn{1}{|c|}{ Priorytet II } & Eącznie & EFS & $\begin{array}{c}\text { Srodki } \\
\text { krajowe }\end{array}$ \\
\hline $\begin{array}{l}\text { Rozwój zasobów ludz- } \\
\text { kich i potencjału adapta- } \\
\text { cyjnego przedsiębiorstw }\end{array}$ & $\begin{array}{c}672298 \\
\text { tys. EUR }\end{array}$ & $\begin{array}{c}571453 \\
\text { tys. EUR }\end{array}$ & $\begin{array}{c}100844 \\
\text { tys. EUR }\end{array}$ \\
\hline
\end{tabular}

niu inicjatyw mających na celu poprawę konkurencyjności przedsiębiorstw poprzez wspieranie współpracy między nimi oraz między przedsiębiorstwami i innymi instytucjami, jak np. jednostki naukowe. Wsparcie finansowe przeznaczone na tworzenie i rozwój klastrów wykorzystane efektywnie, pozwoli stworzyć odpowiednie warunki funkcjonowania sieci kooperacyjnych, klastrów w Polsce.

Konkurencyjność i innowacyjność przedsiębiorstw w gospodarce wiążą się bezpośrednio zarówno $\mathrm{z}$ rozwojem lokalnej zdolności innowacyjnej, jak i dostępnością globalnych zasobów. Klastry i sieci wyłaniają się jako istotne narzędzia promocji regionalnego rozwoju, wsparcia wzrostu MŚP, zmniejszania przestrzennych i społecznych nierówności oraz rozprowadzania i rozwoju lokalnie zdobywanej wiedzy [4, s. 1$]$.

dr Matgorzata Baran

doktorantka WNEiZ

Uniwersytetu Mikołaja Kopernika w Toruniu

\section{BIBLIOGRAFIA}

[1] BRODZICKI T., SZULTKA S., TAMOWICZ P., Polityka wspierania klastrów. Najlepsze praktyki. Rekomendacje dla Polski, Niebieskie Księgi 2004, Rekomendacje nr 11, IBnGR, Gdańsk 2004

[2] European Commission, European Trend Chart on Innovation, Trend Chart Policy Workshop „Innovative Hot Spots in Europe: Policies to Promote Trans-border Clusters of Creative activity", Luxembourg 2003.

[3] European Commission, Regional Clusters in Europe, Observatory of European SMEs, no 3, 2002.

[4] PORTER M.E., Local Competition and Economic Development: Local Clusters in a Global Economy, „Economic Development Quarterly", luty 2000, vol. 14.

[5] Porter M.E., Porter o konkurencji, PWE, Warszawa 2001. [6] Program Operacyjny „Innowacyjna Gospodarka”, 20072013. Narodowa Strategia Spójności 2007-2013, Ministerstwo Rozwoju Regionalnego, Warszawa, 5 maja 2006.

[7] Program Operacyjny „Kapitał Ludzki” 2007-2013. Narodowa Strategia Spójności 2007-2013 (projekt), Ministerstwo Rozwoju Regionalnego, Warszawa, maj 2006.

[8] SZULTKA S., Klastry. Innowacyjne wyzwanie dla Polski, IBnGR, Gdańsk 2004.

\section{Summary}

Observations of phenomenon occurring particularly in developed economies reveal, that clusters influence innovativeness and competitiveness of both: cluster members and regional economies.

Support of regional development based on cluster phenomenon is a new tool of regional politics in Poland, which is in reflected in Structural Funds programme documents. Clusters will be developed and supported by funds of Financial Perspectives 2007-2013 in accordance with Operational Programmes: Innovative Economy and Human Capital, as well as Regional Operational Programmes, in which influence of clusters and cooperative networks on development of companies and regions is particularly outlined. 


\title{
Regionalne wsparcie finansowe matych is šrednich przedsiębiorstw Empiryczna analiza porównawcza Malopolski i Śląska
}

\author{
Krzysztof Wach
}

\section{Wprowadzenie}

W zrastająca liczba opracowań, zawierających wiele zróżnicowanych ujęć uwarunkowań funkcjonowania i rozwoju małych i średnich przedsiębiorstw $\mathrm{w}$ aspekcie regionalnym, odzwierciedla wyraźną fragmentaryczność wiedzy naukowej $\mathrm{w}$ tym zakresie. O ile w literaturze przedmiotu, zarówno krajowej, jak i zagranicznej, istnieje zgodność co do tezy, że czynniki otoczenia regionalnego odgrywają istotne znaczenie w powstawaniu, przetrwaniu, funkcjonowaniu i rozwoju małych i średnich przedsiębiorstw, o tyle jednak brakuje zgodności w zakresie identyfikacji tych czynników oraz ich parametryzacji.

Jak wskazują zarówno liczne opracowania teoretyczne (Europe's Changing..., 2003; SMEs and Access..., 2003; Raport roczny..., 2005, s. 43), jaks i liczne badania empiryczne (Porter, 2001; Frenkel, 2001; Bergman, Japsen, Tamásy, 2002; Sternberg, Litzenberg, 2004), jednym z kluczowych czynników warunkującym powstawanie, przetrwanie i rozwój mikro-, małych i średnich przedsiębiorstw jest dostępność kapitału oraz wsparcia finansowego na poziomie regionalnym, zwłaszcza w początkowym stadium rozwoju tych przedsiębiorstw.

Celem artykułu jest empiryczna weryfikacja wpływu czynników otoczenia regionalnego związanych $\mathrm{z}$ dostępnością kapitału i wsparcia finansowego $\mathrm{w}$ badanym regionie na rozwój badanych małych i średnich przedsiębiorstw. Region na potrzeby badań porównawczych zostal zdefiniowany zgodnie $z$ europejską nomenklaturą statystyczną NUTS-1 jako region Polski Południowej (tzw. region II lub region południowy) obejmujący województwo małopolskie i śląskie.

Na potrzeby badań empirycznych posłużono się losową próbą badawczą, która obejmowała 109 przedsiębiorstw z sektora MŚP zlokalizowanych w regionie południowym, z czego 49 w Małopolsce oraz 60 na Śląsku. Pomocniczą grupę badawczą stanowiły gminy $\mathrm{z}$ badanego regionu (wysłano ankiety do wszystkich 349 gmin regionu, a otrzymano także 131 kompletnych ankiet). Jako metodę operacjonalizacji wybrano percepcję menedżerską, która zapewnia akceptowalną poprawność i rzetelność, a przede wszystkim przewyższa inne metody pod względem praktyczności zastosowania. Jest bardzo często stosowana w analogicznych badaniach (Lyon, Lumpkin, Dess, 2000, s. 1055; Konecki, 2000, s. 86). Jako podstawowe narzędzie badawcze oparte na przyjętych zmiennych i ich operacjonalizacji skonstruowano kwestionariusz ankiety służący do realizacji przyjętej techniki badawczej. Stąd dla ewaluacji regionalnego wsparcia finansowego oraz poziomu rozwoju badanych przedsiębiorstw zastosowano pięciostopniową skalę Likerta $\mathrm{z}$ odpowiedziami jakościowymi. Do analizy wyników zastosowano zarówno statystyki opisowe (takie jak średnia arytmetyczna, modalna, mediana, kwartale), jak i statystyczne narzędzia weryfikacji hipotez (test chi-kwadrat, korelacja liniowa Pearsona). Na potrzeby badań przyjęto typowy poziom $\mathrm{p}<0,05$ jako poziom do testowania hipotez, a za dopuszczalny poziom $\mathrm{p}<0,1$. W celu weryfikacji hipotez zastosowano dwa wskaźniki syntetyczne - zmienne, a mianowicie menedżerską ocenę regionalnego wsparcia finansowego $\left(\mathrm{E}_{1}\right)$ oraz ogólny wskaźnik rozwoju badanych przedsiębiorstw $\left(D_{0}\right)$.

\section{Percepcja menedżerska regionalnego wsparcia finansowego}

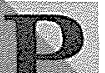

onad dwie trzecie badanych przedsiębiorców z Małopolski negatywnie ocenia dostępność kapitału i wsparcia finansowego w województwie, przy czym nie ma statystycznie istotnych różnic $\left(\chi^{2}=0,94, p=0,3\right)$ w ocenach tego czynnika przez przedsiębiorców korzystających $65 \%$ negatywnych ocen) lub niekorzystających (78\% negatywnych ocen) z zewnętrznych źródeł finansowania. Nie zaobserwowano również statystycznie istotnych różnic w ocenie tego czynnika ze względu na parametry demograficzne badanych przedsiębiorców i kierowanych przez nich przedsiębiorstw, niemniej jednak na podstawie rozkładu dwuwymiarowego częstości odpowiedzi zaobserwowano następujące prawidłowości. Regionalne wsparcie finansowe w województwie małopolskim jest częściej oceniane negatywnie przez:

- firmy starsze (74\%) niż mlodsze $(60 \%)$, 